\title{
Питання національних меншин у розвитку транскордонної співпраці Карпатського єврорегіону
}

УДК 327.8

DOI https://doi.org/10.24195/24149616.2021-2.23

Соколовський Олександр Богданович orcid.org/0000-0002-0515-2367 аспірант кафредри політології та міжнародних відносин Національного університету «Львівська політехніка» вул. Степана Бандери, 12, Львів, Україна

\begin{abstract}
У статті досліджено роль національних меншин у розвитку транскордонної співпраці у Карпатському єврорегіоні. Єврорегіон «Карпати» $є$ одним із найбільших єврорегіонів на теренах Східної та Центрально-Східної Європи, до якого входять такі держави, як Україна, Польща, Словаччина, Угорщина та Румунія. Стратегія ефективного розвитку єврорегіону дає чудові можливості для розширеного політичного діалогу, а також поглибленої економічної, культурної та міжетнічної співпраці. Чимало проєктів у рамках цього єврорегіону покликані перш за все розщирити співпрацю з національними меншинами, а також сприяти політиці культурного різноманіття в регіоні та створенню єдиної, добре розвиненої інфрраструктури. Від початку свого заснування Карпатський єврорегіон перейшов від декларативного утворення до ефективного та практичного інструменту в багатосторонній дипломатії. Мета створення Карпатського єврорегіону полягала в забезпеченні належного розвитку для членів у координації транскордонного співробітництва, сприянні більш швидкому регіональному та економічному розвитку та, звісно, створенню добросусідських відносин відносини між зацікавленими сторонами. Попри че, Карпатський єврорегіон є чималим, і томо є деяка нерівномірність у співпраці між державами-учасницями процесу. Аналіз показав, що співпраця між Польщею та Україною є значно потужнішою, ніж співпраця між Польщею та Словаччиною. Звичайно, першою причиною такої нерівномірності у співпраці є спільне історичне минуле, а також наявність національних меншин, які i задають основну тенденцію та є основним елементом практичної реалізації співпраці між сторонами. 3 іншої сторони, деякі держави-члени мають певні побоювання щодо активної участі окремих національних меншин, перш за все це стосується Угорщини та угорської начіональної меншини в Україні, Словаччині та Румунії. Центральна влада Угорщини є дуже різкою у висловлюваннях та постійно піддає критиці інші уряди та активно заохочує до розширення прав угорської національної меншини, що негативно сприймається їі сусідами. Тому недивно, що участь Угорщини в транскордонній співпраці $є$, але вона є непомітною та не такою ефективною, як з іншими сторонами процесу, зокрема це стосується Польщі-України чи Румунії-України. Ключові слова: транскордонна співпраця, єврорегіон, єврорегіон «Карпати», національні меншини, Польща, Україна, Словаччина, Румунія, Угорщина.
\end{abstract}

Вступ. Транскордонна співпраця є важливим елементом системи регіональної політики та чинником безпеки Європейського Союзу та її сусідів, у тому числі України. Ці відносини встановлені на регіональному рівні серед органів місцевого самоврядування, створюють міцну основу для співпраці і сприяють успішній внутрішній політиці та поглибленні європейської інтеграції.

Одним із головних завдань єврорегіональної транскордонної співпраці $€$ комплексний розвиток прилеглих прикордонних регіонів шляхом розширення комерційних, економічних, гуманітарних, культурних, освітніх, академічних зв'язків, транскордонна співпраця в реалізації спільних інтересів у сорері охорони навколишнього середовища, збереження культурної спадщини, розвиток логістики прикордонної інфрраструктури.

Транскордонні регіони, що входять до складу Карпатського єврорегіону, характеризуються різним рівнем політичного й економічного устрою. До прикладу, Польща, Угорщина та Словаччина порівняно швидко подолали труднощі початкового періоду трансформацій і стали на шлях сталого економічного розвитку, відзначаються політичною стабільністю і $€$ повноправними державами-учасницями НАТО (1999р.) та Європейського Союзу (2004 р.). Рівень корупції там низький. Засоби масової інфрормації вільні і незалежні. Також у цих країнах функціонує порівняно сильна і добре організована громадська ініціатива.

Своєю чергою Румунія та Україна вибрали шлях повільних і косметичних реформ, напрям яких часто змінюється. Країни характеризуються внутрішньополітичною нестабільністю, перехідною економікою, корумпованістю та демонструють слабкість у повноцінному реформуванні. Демократичні і державні інститути ще нестабільні. Попри це, Румунія більш вдало вийшла з цієї кризи, і їй вдалося реорганізувати свою економіку, а також подолати корупцію. З 2004 року вона член НАТО, з 2008 року стала членом Європейського Союзу (хоча і з деякими обмеженнями). В Україні ж є незацікавленість правлячої верхівки радикально змінити застарілу систему, покласти край корупції, олігархізму, кумівству. До того ж обидві країни страждають від маси бюрократичних обмежень, некомпетентності чиновників, провалу адміністративно-територіальних реформ, що ускладнюють розвиток регіонального й транскордонного співробітництва. Хоча Україна за останні десятиліття і стала на шлях євроінтеграції, було сорормовано активне громадянське суспільство, а також були зроблені певні кроки в реформі кожної сорери життя, всі кроки є невеликими, а рішення приймаються вкрай повільно. 
Транскордонне співробітництво в рамках Карпатського єврорегіону $€$ важливим інструментом багатосторонньої співпраці, попри це, кожна держава-учасниця цього процесу має вкрай різні погляди на неї.

До питання дослідження транскордонної співпраці в рамках Карпатського єврорегіону найбільш активно залучені українські та польські науковці, оскільки 3 їх сторони ця співпраця $€$ найбільш результативною та ефективною. Так, до представників польської наукової групи можна зарахувати таких дослідників, як М. Гільда, Е. Кацперска, П. Лазутка, Л. Левковіц та інші. Польські науковці особливо увагу приділяють прикордонному та регіональному співробітництву, а також активно досліджують вплив національних меншин на цю співпрацю. Чимало польських проєктів у рамках транскордонного співробітництва Карпатського єврорегіону ставлять за мету поглиблену економічну та культурну співпрацю між сторонами.

Українське наукове коло теж має чимало дослідників у сорері транскордонного співробітництва. Слід зазначити таких дослідників, як І. Артьомов, В. Герасимчук, В. Гоблик, Я. Малик, Н. Мікула та інших. У полі зору українських науковців перебувають, насамперед, більш теоретичні аспекти транскордонної співпраці, ніж практичні. Особливу увагу українські науковці приділяють не скільки участі національних меншин у транскордонній співпраці, скільки принципам фрормування та розвитку єврорегіону чи економічним перспективам співробітництва держав-учасниць. Дослідження у сорері транскордонної співпраці вкрай варіюються, проте слід зазначити, що усі науковці сходяться на думці, що Карпатський єврорегіон $€$ перспективним і співпрацю в рамках нього потрібно розширювати. Аналіз наукової літератури показав, що проблематика ролі національних меншин у розвитку транскордонної співпраці є малодослідженою, не вистачає системних наукових досліджень.

Мета та завдання. Мета - дослідити роль національних меншин у розвитку транскордонної співпраці Карпатського єврорегіону, проаналізувати європейський досвід залучення і використання можливостей співпраці 3 національними меншинами в поліетнічних прикордонних регіонах.

Методи дослідження. У статті використано комплекс загальнонаукових методів, зокрема, теоретичного узагальнення, історичного, порівняння, аналізу, структурно-фрункціональний. Методологічною основою дослідження транскордонного співробітництва $€$ міждисциплінарний підхід, зокрема поєднання системного і структурно-функціонального аналізу; інституціональний підхід - дослідження впливу на транскордонне співробітництво організацій національних меншин.

Результати. Офіційне оформлений Карпатський єврорегіон у 1992 р. у м. Ніредьгаза (Угор- щина), за ініціативи експертів Інституту досліджень Схід-Захід, відбулась зустріч місцевих та регіональних лідерів із метою визначення перспектив розвитку транскордонного співробітництва у регіоні Карпат і Тисянської долини. У цьому ж році в м. Ужгороді (Україна) представники зацікавлених регіонів підготували основоположні документи об'єднання - Угоду і Статут. Згідно з положеннями Статуту, місія єврорегіону полягала в заохоченні і підтримці громадських ініціатив, налагодженні діалогу між територіальними громадами, органами місцевого самоврядування та неурядовими організаціями, покращенні якості життя населення, запобіганні територіальних суперечок, розвитку інфрраструктури, забезпеченні прозорості кордонів та ефективного використання природних ресурсів, а також збереженні унікальної культурної спадщини Карпатського регіону.

Після низки зустрічей та раундів переговорів 14 лютого 1993 р. у м. Дебрецен (Угорщина) міністри закордонних справ Угорщини, Польщі, України ухвалили Декларацію про заснування Карпатського єврорегіону [1].

Варто зазначити, що ставлення центральних урядів до участі певних територій у такій фундації було неоднозначне. Для прикладу, лідери Словаччини мали певні побоювання, що участь у таких угодах окремих територій супроводжуватиме до надання їм більших повноважень на регіональному і місцевому рівні. Правляча еліта вважала, що таке співробітництво призведе до розмиття територіальних кордонів, спричинить втрату національного суверенітету. Однак справжні причини таїлись значно глибше - Словаччина відверто боялась відродження Угорської «імперії», внаслідок приєднання всіх земель, де проживають її етнічні меншини, до цього списку потрапляла й Словацька Республіка. Лише в 1999 р., на сьомому році існування Карпатського єврорегіону, його словацькі члени змінили свій статус з асоційованих на повноправні.

Повіти Румунії у 1993 р. набули лише статусу спостерігача, що було зумовлено недосконалістю національного законодавства, яке визначає повноваження регіональних та місцевих органів, а отже, рівень їх компетенції в налагодженні співробітництва 3 суміжними прикордонними територіями. Після початку регіональної рефрорми в Румунії, активної лобістської кампанії представників північно-західних повітів влітку 1997 р. 5 повітів стали повноправними членами єврорегіону [2].

Не варто вважати, що й українська сторона відразу висловилася за вступ західних областей країни до складу цієї міжнародної асоціації. Частина політичних сил відстоювала принцип непорушності кордонів, виключні права центральних органів влади і абсолютно заперечувала будь-яку участь адміністративно-територіальних одиниць у такому транскордонному утворенні. І, що цікаво, 
їхні аргументи часто збігалися з позицією словацької сторони щодо «угорської загрози» та її експансіоністських амбіцій [3].

Ось чому утворення Карпатського єврорегіону вважається ретельно зваженим дипломатичним кроком молодих і ще тоді не зовсім компетентних держав Центрально-Східної Європи. Через побоювання щодо автономізму областей, країв, повітів національні уряди включили до складу Карпатського єврорегіону досить значну кількість адміністративно-територіальних одиниць, що зумовило надмірність територіального розширення та неможливість впровадження багатостороннього співробітництва [4].

Попри різнорідний рівень розвитку країн-членів Карпатського єврорегіону, їх об'єднує перелік особливостей, характерний для функціонування єврорегіонів як фрорми транскордонного співробітництва.

По-перше, правове регулювання на території кожної 3 країн-учасниць Асоціації здійснюється відповідно до чинного законодавства держави, до якої вона належить, а керівні органи асоціації виконують суто координаційні фрункції і не мають владних повноважень.

По-друге, кожна країна-учасниця Карпатського єврорегіону діє в інтересах своєї країни відповідно до задекларованої зовнішньополітичної концепції.

По-третє, усі прикордонні території, що входять до складу Карпатського єврорегіону, об'єднує спільне історичне минуле, а саме перебування упродовж XVI - XIX століть у складі Габсбурзької Монархії, згодом єдиного державного утворення Австро-Угорщини, що зумовило розбудову спільної транспортної інфраструктури, взаємодоповнюваності ринків, а отже, єдине просторове розташування. Після Другої світової війни Радянський Союз отримав виключне право на володіння всією Центрально-Східною Європою. Однак жорсткий контроль навіть за внутрішніми кордонами країн не зміг ліквідувати дрібну прикордонну торгівлю в регіоні Карпат, взаємодопомогу під час збирання врожаю, періодичність координаційних зустрічей партійної та державної регіональної еліти, традиції студентських обмінів.

По-четверте, $є$ національні та культурні особливості, пов'язані з багатоетнічним (40\% - українці, 19\% - румуни, 16\% - угорці, 15\% - поляки, 2\% - словаки та цигани, 1\% - німці, євреї, молдовани, серби, хорвати) та поліконфесійним (православні - 33\%, римські католики -28\%, грецькі католики - 24\%, протестанти - 8\%, юдеї - 1\%) складом прикордонних територій держав, які входять до складу Єврорегіону [5].

По-п'яте, важливою особливістю територій у складі Карпатського єврорегіону $є$ наявність суміжних проблем транскордонного характеру: уповільнений економічний розвиток; віддаленість від національних центрів та периферійність; відсутність прикордонних переходів; низький рівень транспортної та інфрормаційної інфрраструктури; безробіття, зумовлене відсутністю реальної диверсифрікації економіки регіону; нелегальна міграція; етнічні меншини [6].

По-шосте, чітко визначені спільні інтереси членів Карпатського єврорегіону. В економічній сорері - це розширення транспортної, комунікаційної мереж; вдосконалення пунктів перетину кордону, налагодження безпосередніх зовнішньо-економічних контактів між територіями, заснування кластерів, отримання інноваційного досвіду, залучення іноземних інвестицій. В екологічній сфері це побудова суміжних гідроспоруд, дамб, перехід до альтернативних джерел енергозабезпечення, застосування сучасних способів утилізації сміття та очищення стічних вод, постійний моніторинг за раціональним використанням ресурсів. У гуманітарній сорері - освітній, культурний, спортивний обмін, проведення спільних ярмарків, фрестивалів, змагань, наукових міждержавних коноеренцій, відкриття літніх шкіл, таборів, туристично-рекреаційних комплексів, розробка курсів із вивчення мов сусідніх держав. У політичній сорері - це реалізація концепції регіонального розвитку, усунення просторових бар'єрів, надання переваг ініціативам самоврядних одиниць, територіальних громад, боротьба з політизацією та централізацією структури Карпатського єврорегіону [7].

Як каталізатор регіональних тенденцій розвитку, Карпатський єврорегіон пережив низку організаційних перетворень, щоб найкращим чином служити своїй місії. Організаційна структура єврорегіону «Карпати» включає Раду, виконавчого директора, Міжнародний Секретаріат, національні представництва, робочі комісії.

Вищим керівним органом асоціації є Регіональна Рада, до складу якої входять 15 осіб (по 3 представники від кожної країни-учасниці). До повноважень Ради належить приймати рішення 3 питань транскордонного співробітництва, членства, участі в міжнародних організаціях, створювати робочі комісії, ухвалювати розроблені комісіями проєктні пропозиції та гарантувати умови для їх виконання. Засідання Ради відбуваються кожні шість місяців [8].

Виконавчий директор призначається Радою Карпатського єврорегіону на два роки на підставі конкурсного відбору, який проводиться в регіонахчленах асоціації. До повноважень виконавчого директора входить виконання рішень Ради Карпатського єврорегіону, керівництво Секретаріатом, координація діяльності робочих комісій та національних представників, підготовка проєктів угод, проєктів засідань Ради, підтримка контактів із місцевими та міжнародними інституціями [9].

Організаційним органом Карпатського єврорегіону є Міжнародний Секретаріат, керівником якого 
$€$ виконавчий директор. До обов'язків Секретаріату належить координувати щоденну роботу асоціації, робочих комісій, організовувати засідання Ради та виконувати відповідні адміністративні завдання, підтримувати зв'язки 3 національними офісами, міжнародними організаціями, брати участь у пошуках донорів. Роботу Міжнародного Секретаріату підтримують національні офіси держав-членів асоціації, постійні координатори, які також здійснюють організаційні, перекладацькі та координаційні функції. До складу Секретаріату, окрім виконавчого директора, входить помічник виконавчого директора, секретар [10].

Секретаріат кожні два роки змінює місцезнаходження. Протягом короткої історії існування Карпатського єврорегіону виконавчими директорами були Адам Пеціол (Польща), Пал Віраг (Угорщина), Михайло Буковецький (Україна), Пйотр Гелінський (Польща).

У структурі Карпатського єврорегіону діють 7 робочих комісій, діяльність яких координується положенням, схваленим у квітні 1996 р. на XV засіданні Ради Карпатського єврорегіону. Згідно нього:

- робочі комісії утворюються 3 метою розв'язання різноманітних проблем транскордонного співробітництва або реалізації спеціальних проєктів;

- до складу комісій входять по два представника від кожної національної сторони Карпатського єврорегіону, призначені членами Ради;

- діяльністю комісій керує голова, який представляє національну сторону, на яку покладено завдання щодо координації роботи цієї комісії;

- основним завданням комісій є збір пропозицій щодо проєктів із транскордонного співробітництва, надання допомоги в реалізації кращих із них [11].

Нині в рамках Карпатського єврорегіону функціонує 7 робочих комісій, серед яких - Комісія 3 питань туризму (координатор - польська сторона), Комісія з регіонального розвитку та охорони довкілля (координатор - угорська сторона), Комісія з питань розвитку соціальної інорраструктури (координатор - українська сторона) та ін. Координаційне забезпечення здійснюють національні представництва, що відповідальні за підтримання постійних контактів із Радою. Серед їхніх основних функцій: поглиблення дво- і багатостороннього співробітництва; сприяння реалізації проєктів, ініційованих територіальними громадами; надання інформаційної, технічної та фрінансової допомоги; пошук донорів тощо [12]

Карпатський фронд відіграє роль, так би мовити, посередника між великими міжнародними фрондами, зацікавленими в розвитку транскордонного співробітництва, громадянського суспільства, міжетнічної співпраці, відродженні сіл та міст та місцевими громадськими організаціями, органами місцевого самоврядування, які пропонують своє бачення у вирішенні вищезгаданих проблем. Стратегічними завданнями Карпатського фонду є:

- сприяння поглибленню багатостороннього діалогу між прикордонними регіонами України, Угорщини, Румунії, Польщі та Словаччини;

- розвиток демократії і громадянського суспільства на місцевому та регіональному рівнях;

- реалізація спільних економічних, наукових, екологічних, культурних та освітніх проєктів;

- підвищення соціальної мобільності громад;

- технічна та фрінансова підтримка місцевих ініціатив;

- поглиблення кооперації між самоврядними одиницями, громадами, неурядовими організаціями та органами державної влади;

- попередження конорліктів шляхом розвитку міжетнічного співробітництва та захисту національних меншин;

- забезпечення принципів регіональної політики Європейського Союзу: субсидіарності (коли вищі одиниці мають право і мають розв'язувати рішення в державі, на виконання яких нижчі ланки не здатні), децентралізації (перерозподіл повноважень), партнерства (співробітництво між суб'єктами управління різних адміністративнотериторіальних рівнів);

- розвиток логістичної, туристично-рекреаційної, економічної структури регіону, системи охорони здоров'я, соціального та культурного захисту;

- заохочення іноземного капіталу;

- підтримка ефективності і безпеки кордонів;

- сприяння комплексному соціально-економічному розвитку периферійних територій, зменшення їх відсталості стосовно центру [13].

Карпатський єврорегіон $€$ вкрай активним у плані програм та грантів. Так, для прикладу на теренах України діє чимало програм у рамках проєктів Карпатського єврорегіону. Одна 3 них - Програма підтримки ініціатив місцевих карпатських громад. Програма була створена у 2018 році та діє на теренах чотирьох областей - Львівської, Чернівецької, Івано-Франківської та Закарпатської, де в рамках програми щороку реалізовується від 1 або 2 конкурсних наборів проєктів, за результатами яких переможці отримують приз у розмірі 250000 грн. на реалізацію місцевих громадських ініціатив. Така програма $€$ вкрай ефрективною, особливо в контексті розвитку та вирішенні проблем гірських територій [14].

Важливо зазначити активну діяльність лемків Польщі щодо організації різноманітних транскордонних заходів. Прикладами таких заходів $є$ «Лемківська ватра» у Здині, Міжнародний фольклорний фрестиваль національних та етнічних меншин «Свят під Кичера», «Міжнародна бієнале лемківської культури» у Криниці або «Зустрічі з лемківською культурою» у Гожуві-Великопольському у справі лемківської меншини та фестивалю. 
Окрім цього проєкту, в рамках єврорегіону Карпати на теренах України нині діє біля 30 різноманітних грантів: фротоконкурс «Місцевий розвиток Карпат у дії», Конкурс ініціатив місцевих карпатських громад, Конкурс освітніх обмінів між Львівською, Луганською та Донецькою областей, Конкурси журналістських матеріалів, Грант на підтримку Карпатської мережі регіонального розвитку тощо [15].

Серед великих проєктів, які відбуваються в рамках Карпатського єврорегіону, слід згадати проєкт «Шлях волоської культури на українськопольському прикордонні», який реалізовується спільно з Асоціацією промоції та розвитку Підкарпаття «Pro Carpathia». Бюджет програми становить 66650 євро, а метою програми є збереження культурної та історичної спадщини польсько-українського прикордонного регіону шляхом розробки стежки волоської культури з польської та української сторони кордонну. Проєкт, як очікується, має сприяти відновленню традицій, пов'язаних із волоською культурою та вівчарством, а також розвинути інтегрований туристичний продукт, який пов'язаний із волоською культурою, та зміцнити зв'язки та мережі співпраці між польською та українською стороною, що дасть змогу урізноманітнити туристичні послуги [16].

Ще одним важливим і великими проєктом $\epsilon$ «ПАНТЕРА» - транспортний шлях у районі Перемишля та Нижанкович. Бюджет цього проєкту становить 2463000 євро, а ціллю цього проєкту $€$ покращення комунікаційних сторін між прикордонними територіями, зокрема Старосамбірського та Перемишлянського районів. Завдяки цьому проєкту буде модернізовано дороги до пункту пропуску Нижанковичі-Мальховице, а також створено систему транспортного зв'язку між прикордонними територіями. Окрім покращення інорраструктури, програма стосується і створення певних освітніх програм, а також промоційної діяльності [17].

Проєкт «Світ Карпатських Розет» активно реалізується за підтримки ЄС у рамках транскордонного співробітництва Польща-Білорусь-Україна 2014-2020 (але у зв'язку з глобальною епідемією COVID-19 реалізація проєкту було зміщена). Ціль проєкту - збереження культурної спадщини національних та етнічних меншин у Карпатському регіоні, шляхом транскордонного співробітництва в управлінні культурними та історичними ресурсами Карпат через створення мереж організацій, популяризації місцевих традицій та звичаїв, а також підвищенні компетентності місцевих громад щодо проведенні цієї політики. У кінцевому результаті проєкт передбачає створення спільного польсько-українського Карпатського центру культурної спадщини - «Розети» [18].

Як ми можемо побачити, найбільш плідно працюють польська та українська сторона, зокрема
Львівська та Івано-Франківська область. Водночас ініціатив зі сторони Словаччини, Угорщини чи Румунії зведено до мінімуму, або і взагалі відсутні. 3 польської сторони є деякий рівень транскордонного співробітництва і 3 іншою сусідньою державою - Словаччиною, проте рівень зацікавлення у співпраці між сторонами не $є$ великим. Одним із великих проєктів $€$ «Проєкт удосконалення мережі Єврорегіону Карпати», ціллю якого є реалізація спільних проєктів та грантів, а також створення багатофункціональної міжгалузевої мережі співпраці між двома державами [19].

Прикордонні території Румунії та України реалізували низку спільних проєктів, зокрема, у сфрері малого та середнього бізнесу, екології, забезпеченні культурних і освітніх потреб національної румунської меншини, створили інформаційно-аналітичний центр із питань попередження та запобігання паводкам, успішно співпрацюють на прикордонних водах із метою збереження унікального природного комплексу дельти річки Дунаю. Важливим досягненням можна вважати будівництво міжнародного пункту пропуску «Солотвино - Сігету Мармацієй» на суміжному кордоні обох країн.

Угорщина та Україна успішно співпрацюють у сорері розбудови міжнародної транспортної інорраструктури: серед досягнень - проєкт розвитку мережі автомобільних шляхів у суміжних прикордонних областях у рамках пан'європейського транспортного коридору № 5 [20].

Досить активними є українсько-словацькі відносини в культурно-гуманітарній сорері, які ґрунтуються на обміні студентами, фахівцями, молоддю, підтримці спільних науково-культурних досліджень, проведенні конференцій, семінарів, організації виставок, музичних фестивалів, кінофрорумів, спортивних змагань тощо. На Закарпатті уже котрий рік поспіль проводиться літературний фестиваль «Карпатська ватра», який об'єднує письменників України, Словаччини, Угорщини, Польщі та Румунії [21].

Попри це, у 2020 році відбулася зустріч представників усіх держав-членів співробітництва, та було охарактеризовано основні питання та перспективи розвитку регіону. Попри це, найбільш активно дискутували щодо майбутніх проєктів між собою польсько-українська делегація, а також словацько-угорсько-румунська сторона. Це свідчить про те, що кожна $з$ держав-учасниць єврорегіону вже встановила собі перспективні напрями, і найбільш плідно співпраця буде відбуватися для України з Польщею. Незважаючи на це, на зустрічі усі погодилися на проблемах, пов'язаних із сталим розвитком регіонів, екологічних проблемах, збільшенні освітніх програм, покращенні інфраструктури, а також діях щодо подолання епідемії COVID-19 [22].

В Європейському Союзі, а також в інших розвинених регіонах світу досить загальноприйнятим 
уявленням, що сучасний регіональний розвиток базується на розвитку людських ресурсів. Отже, для лідерів Карпатського єврорегіону розвиток освіти та навчання та заохочення інвестицій та відновлення підприємництва можуть означати основні точки прориву, а підтримка пріоритетів, пов'язаних із цим, та реалізація програм можуть мати першочергове значення у піднесенні регіону. Міжрегіональна асоціація Карпатського єврорегіону може відігравати вирішальну роль у прийнятті та реалізації оперативних програм щодо відновлення та заохочення інвестицій, а також щодо освіти, навчання та працевлаштування, які вже були затверджені керівництвом проектів. Уряди-члени єврорегіону мають продовжувати свою активну участь та співпрацю у всіх сорерах від економічної до культурної та міжетнічної співпраці, і допомогти в цьому можуть безпосередньо національні меншини, які хоч і розділені кордоном, проте є основним елементом ефективності єврорегіону.

Отже, єврорегіон Карпати є одним з інструментів Європейського Союзу у проведенні успішної та ефективної політики сталого розвитку регіонів, активному залученні нових партнерів. Попри те, що єврорегіон «Карпати» $€$ формально одним із найбільших в Європі та включає в себе п'ять держав-учасниць, не усі члени активно взаємодіють між собою. Якщо польська сторона активно взаємодіє з українською, то це перш за все через спільне історичне минуле та культурну спадщину. 3 угорської сторони така віддача не дуже і відчутна, перш за все, через певні образи, а також зверхнє ставлення угорської правлячої еліти, яка намагається диктувати свої правила гри для української сторони та доволі часто діє не в правовому полі. Попри це, можна сказати впевнено, що Карпатський єврорегіон продовжить свій розвиток, а сторони - поглиблення співпраці та розширення інструментарію для співробітництва.

Висновок. Отже, розглянуті особливості транскордонного співробітництва в рамках Карпатського єврорегіону демонструють, що усталені економічні, культурні, політичні, міжетнічні контакти між прилеглими територіями сусідніх держав були цілком природними, спричиненими історичним минулим, спільними інтересами та ідентичними проблемами. Національні сторони, всупереч недосконалості законодавства та побоюванням втрати суверенітету, лише легітимізували відносини шляхом підписання міжнародних та транскордонних угод. Офріційне оформлення Карпатського єврорегіону відкрило нові можливості розвитку транскордонної співпраці на багатосторонньому рівні. Своєю чергою ЄС, усвідомлюючи значимість та важливість такого співробітництва, створює нові механізми підтримки та фрінансування. Транскордонна співпраця з питань розвитку національних меншин спрямована на гармонізацію міжнаціо- нальних відносин, збереження і розвиток етнічної самобутності національних меншин. У прикордонних регіонах особлива увага приділяється розвитку освіти, культури, збереженню самобутності національних меншин, задоволенню потреб національних меншин у сорері культури, збереженню традицій та звичаїв. Також активно практикується проведення тематичних семінарів, практикумів та тренінгів у закладах освіти, де навчаються представники національних меншин. Особлива увага у прикордонних регіонах приділяється співпраці навчальних, культурних закладів із зарубіжними партнерами, в тому числі обміну групами науковців, вчителів, студентів, учнів, працівників культури і мистецтва для участі в конореренціях, семінарах, тренінгах. Також практикується відзначення пам'ятних дат, ювілеїв, урочистих подій громадськими організаціями національних меншин. Аналіз показав, що за останні роки значно активізувалась діяльність органів місцевої влади з організації та проведення міжнародних заходів, спрямованих на поглиблення співпраці з прикордонними регіонами і міжнародними організаціями з питань національних меншин.

Практика показує, що участь України і її прикордонних областей у Карпатському єврорегіоні сприяє інтеграції до європейської спільноти, а досвід Закарпатської, Львівської, Івано-Франківської та Чернівецької областей послужив механізмом розширення повноважень місцевих громад і органів влади у сорері налагодження транскордонних взаємин.

\section{ЛІТЕРАТУРА:}

1. Артьомов І. Транскордонне співробітництво як важливий чинник підвищення регіональної конкурентоспроможності. Ужгород: Науковий вісник Ужгородського університету. 2013. URL: https:// dspace.uzhnu.edu.ua/jspui/bitstream/lib/981/1/TPAHСКОРДОННЕ\%20СПІВРОБІТНИЦТВО.pdf

2. Гоблик В. Принципи формування та розвитку транскордонних регіонів України та європейського союзу. Економіка та держава. 2015. URL: http:// www.economy.in.ua/pdf/6 2015/6.pdf

3. Дацій О., Андрющенко К. Транскордонне співробітництво на територіях Карпатського єврорегіону в умовах розвитку міжнародних економічних зв'язків та глобалізації. 2020. URL: http:// www.economy.nayka.com.ua/pdf/11_2020/25.pdf

4. Карпатський єврорегіон: п'ять країн, одна екосистема. Єврорегіон Карпати-Україна. 2020. URL: https://ekarpaty.com/pro-nas/yevroregion/

5. Куліш Н., Герасимчук В. Транскордонне співробітництво регіонів України. 2009. URL: http:// probl-economy.kpi.ua/pdf/2009_9.pdf

6. Малик Я. Транскордонне співробітництво України з Європейським союзом. Демократичне врядування. 2014. URL: http://lvivacademy.com/ vidavnitstvo_1/visnik13/fail/Malyk.pdf

7. Мікула Н. Міжтериторіальне та транскордонне співробітництво. Львів : IPД НАН України, 2004. URL: 
http://znc.com.ua/ukr/publ/book/book-mikula-2004/ book-mikula-2004.pdf

8. Пантера - транспорт в районі Перемишля та Нижанкович за спадщину співпраці. Єврорегіон Карпати-Україна. 2020. URL: https://ekarpaty.com/nashiproekty/panther/

9. Програма підтримки ініціатив місцевих карпатських громад. Єврорегіон Карпати-Україна. 2020. URL: https://ekarpaty.com/our-programs/programapitrymky-initsiatyv/

10. Світ Карпатських розет - заходи зі збереження унікальності культури Карпат. Єврорегіон КарпатиУкраїна. 2020. URL: https://ekarpaty.com/nashi-proekty/ rosettes/

11. Шлях волоської культури на українсько-польському прикордонні. Єврорегіон Карпати-Україна. 2020. URL: https://ekarpaty.com/nashi-proekty/shlyahvoloskoyi-kulturi/

12. Benč, V., Dumitru, A., Geszterédi, A. The Carpathian Euroregion Strategy 2020 \& Beyond. 2015. URL: http://carpathianeuroregion.org/letolt/strategiaenglish.pdf

13. Bilicik, V., Duleba, A., Klyab, M., Mitryayeva, S. Role of the Carpathian Euroregion in Confronting its Minority Agenda. 2001. URL: http://www.policy.hu/flora/ carpathianmin.pdf

14. Kacperska, E. Współpraca transgraniczna a rozwój regionów wschodnich. 2005. URL: http:// sj.wne.sggw.pl/pdf/EIOGZ_2005_n55_s5.pdf

15. Kusiak-Winter, R. Wspolopraca transgraniczna w administracji publicznej. Wydział Prawa, Administracji i Ekonomii Uniwersytetu Wrocławskiego. 2015. URL: https://www.bibliotekacyfrowa.pl/Content/71621/ PDF/Wspolpraca_transgraniczna_w_administracji_ publicznej.pdf

16. New Ways for Europe: Pan-European Corridor 5. 2009. URL: https://www.dywidag-systems.com/ projects/2010-info-18/new-ways-for-europe-paneuropean-corridor-5/

17. Shaban, T. Euroregion as an Important Mechanism of Cross-border Cooperation Between Ukraine and the European Union. 2015. URL: https:// biglobalization.org/sites/default/files/uploads/files/big_ research_project_39_governance_shaban.pdf

18. Skoczylas, Ł. A ktualnawspółpracatransgraniczna Rzeczypospolitej Polskiej modelująca aktywność międzynarodową samorządów. 2012. URL: https:// repozytorium.uwb.edu.pl/jspui/bitstream/11320/1978/1/ BSP_12_2012_Skoczylas.pdf

19. Smętkowski, M., Rok, J. The Carpathian Euroregion from the perspective of economic cooperation in peripheral regions. Centre for European Regional and Local Studies. 2016. URL: https://mpra.ub.unimuenchen.de/82763/1/MPRA_paper_82763.pdf

20. Suli-Zakar, I. Successes and Failures in the CBC History of East Europe. 2014. URL: https:// journals.indexcopernicus.com/api/file/viewByFileld/334142.pdf

21. Systemowy Projekt Sieciowy Euroregionu Karpackiego. Euroregion Karpacki. 2012. URL: http:// www.karpacki.pl/stowarzyszenie-karpaty/projektywlasne-zakonczone/systemowy-projekt-sieciowy/

22. Tanaka, H. Carpathian Euroregion and Cross-Border Governance. 2006. URL: https://www. semanticscholar.org/paper/Carpathian-Euroregion-and-
Cross-Border-Governance-Tanaka/ec055f697dac7de5a 7b0ab0109a81fb77a4b6816

\section{REFERENCES}

1. Artomov, I. (2013). Transkordonne spivrobitnytstvo yak vazhlyvyi chynnyk pidvyshchennia rehionalnoi konkurentospromozhnosti [Cross-border cooperation as an important factor in increasing regional competitiveness]. Uzhhorod: Naukovyi visnyk Uzhhorodskoho universytetu. URL: https://dspace.uzhnu.edu.ua/jspui/bitstream/lib/981/ 1/ТРАНСКОРДОННЕ\%20СПІВРОБІТНИЦТВО.pdf [in Ukrainian].

2. Hoblyk, V. (2015). Pryntsypy formuvannia ta rozvytku transkordonnykh rehioniv Ukrainy ta yevropeiskoho soiuzu [Principles of formation and development of cross-border regions of Ukraine and the European Union]. Ekonomika ta derzhava. URL: http:// www.economy.in.ua/pdf/6_2015/6.pdf [in Ukrainian].

3. Datsii, O., Andriushchenko, K. (2020). Transkordonne spivrobitnytstvo na terytoriiakh Karpatskoho yevrorehionu $v$ umovakh rozvytku mizhnarodnykh ekonomichnykh zviazkiv ta hlobalizatsii [Cross-border cooperation in the Carpathian Euroregion in the conditions of development of international economic relations and globalization]. URL: http://www.economy.nayka.com.ual pdf/11_2020/25.pdf [in Ukrainian].

4. Karpatskyi Yevrorehion: piat krain, odna ekosystema. (2020). [Carpathian Euroregion: five countries, one ecosystem]. Yevrorehion Karpaty-Ukraina. URL: https:// ekarpaty.com/pro-nas/yevroregion/ [in Ukrainian].

5. Kulish, N., Herasymchuk, V. (2009). Transkordonne spivrobitnytstvo rehioniv Ukrainy [Crossborder cooperation of the regions of Ukraine]. URL: http:// probl-economy.kpi.ua/pdf/2009_9.pdf [in Ukrainian].

6. Malyk, Ya. (2014). Transkordonne spivrobitnytstvo Ukrainy z Yevropeiskym soiuzom [Ukraine's crossborder cooperation with the European Union. Democratic governance]. Demokratychne vriaduvannia. URL: http:// Ivivacademy.com/vidavnitstvo_1/visnik13/fail/Malyk.pdf [in Ukrainian].

7. Mikula, N. (2004). Mizhterytorialne ta transkordonne spivrobitnytstvo [Interterritorial and cross border cooperation]. Lviv: IRD NAN Ukrainy. URL: http:// znc.com.ua/ukr/publ/book/book-mikula-2004/bookmikula-2004.pdf [in Ukrainian].

8. Pantera - transport $v$ raioni Peremyshlia ta Nyzhankovych za spadshchynu spivpratsi [Panther transport in the area of Przemyśl and Nyżankowicz for the legacy of cooperation]. (2020). YevrorehionKarpaty-Ukraina. URL: https://ekarpaty.com/nashi-proekty/panther/ [in Ukrainian].

9. Prohrama pidtrymky initsiatyv mistsevykh karpatskykh hromad [Program to support initiatives of local Carpathian communities]. (2020). Yevrorehion Karpaty-Ukraina. URL: https://ekarpaty.com/our-programs/ programa-pitrymky-initsiatyv/ [in Ukrainian].

10. Svit Karpatskykh rozet - zakhody zi zberezhennia unikalnosti kultury Karpat [The world of Carpathian rosettes - measures to preserve the uniqueness of Carpathian culture]. (2020). Yevrorehion Karpaty-Ukraina. URL: $\quad$ https://ekarpaty.com/nashi-proekty/rosettes/ [in Ukrainian].

11. Shliakh voloskoi kultury na ukrainsko-polskomu prykordonni [The way of Wallachian culture on the 
Ukrainian-Polish border]. (2020). Yevrorehion KarpatyUkraina. URL: https://ekarpaty.com/nashi-proekty/ shlyah-voloskoyi-kulturi/ [in Ukrainian].

12. Benč, V., Dumitru, A., Geszterédi, A. (2015). The Carpathian Euroregion Strategy 2020 \& Beyond. URL: http://carpathianeuroregion.org/letolt/strategiaenglish.pdf

13. Bilicik, V., Duleba, A., Klyab, M., Mitryayeva, S. (2001). Role of the Carpathian Euroregion in Confronting its Minority Agenda. URL: http://www.policy.hu/flora/ carpathianmin.pdf

14. Kacperska, E. (2005). Współpraca transgraniczna a rozwój regionów wschodnich [Cross-border cooperation and the development of eastern regions]. URL: http:// sj.wne.sggw.pl/pdf/EIOGZ_2005_n55_s5.pdf [in Polish].

15. Kusiak-Winter, R. (2015). Wspolopraca transgraniczna w administracji publicznej [Cross-border cooperation in public administration]. Wydział Prawa, Administracji i Ekonomii Uniwersytetu Wrocławskiego. URL: https://www.bibliotekacyfrowa.pl/Content/71621/ PDF/Wspolpraca_transgraniczna_w_administracji_ publicznej.pdf [in Polish].

16. New Ways for Europe: Pan-European Corridor 5. (2009). URL: https://www.dywidag-systems.com/ projects/2010-info-18/new-ways-for-europe-paneuropean-corridor-5/

17. Shaban, T. (2015). Euroregion as an Important Mechanism of Cross-border Cooperation Between
Ukraine and the European Union. URL: https:// biglobalization.org/sites/default/files/uploads/files/big_ research_project_39_governance_shaban.pdf

18. Skkoczylas, Ł. (2012). Āktualna współpraca transgraniczna Rzeczypospolitej Polskiej modelująca aktywność międzynarodową samorządów [The current cross-border cooperation of the Republic of Poland modeling the international activity of local governments]. URL: https://repozytorium.uwb.edu.pl/jspui/bitstream/ 11320/1978/1/BSP 122012 Skoczylas.pdf [in Polish].

19. Smętkowski, M., Rok, J. (2016). The Carpathian Euroregion from the perspective of economic cooperation in peripheral regions. Centre for European Regional and Local Studies. URL: https://mpra.ub.uni-muenchen. de/82763/1/MPRA paper 82763.pdf

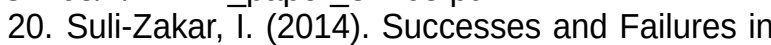
the CBC History of East Europe. URL: https://journals. indexcopernicus.com/api/file/viewByFileld/334142.pdf

21. Systemowy Projekt Sieciowy Euroregionu Karpackiego (2012). Euroregion Karpacki. URL: http:// www.karpacki.pl/stowarzyszenie-karpaty/projektywlasne-zakonczone/systemowy-projekt-sieciowy/ [in Polish].

22. Tanaka, H. (2006) Carpathian Euroregion and Cross-Border Governance. URL: https://www. semanticscholar.org/paper/Carpathian-Euroregionand-Cross-Border-Governance-Tanaka/ec055f697 dac7de5a7b0ab0109a81fb77a4b6816

\section{Issue of national minorities in the development of cross-border cooperation of the Carpathian Euroregion}

Sokolovskyy Oleksandr Bohdanovych

\section{Postgraduate Student} at the Department of Political Science and International Relations Lviv Polytechnic National University Stepan Bandera str., 12, Lviv, Ukraine
The article examines the peculiarities of the formation of the Carpathian Euroregion, the peculiarities of cooperation and the role of national minorities in this cooperation. The Carpathian Euroregion is one of the largest Euroregions in Eastern and Central and Eastern Europe, and includes countries such as Ukraine, Poland, Slovakia, Hungary and Romania. The strategy for the effective development of the Euroregion provides excellent opportunities for enhanced political dialogue, as well as in-depth economic, cultural and interethnic cooperation. Many projects within this Euroregion are primarily aimed at expanding cooperation with national minorities, as well as policies of cultural diversity in the regions and the creation of a single, well-developed infrastructure. Since its inception, the Carpathian Euroregion has moved from a declarative formation to an effective and practical too in multilateral diplomacy. In the European Union it is a fairly common notion that modern regional development is based on human resource development. Thus, for the leaders of the Carpathian Euroregion, the development of education and training and the promotion of investment and resumption of entrepreneurship can be key breakthroughs, and supporting related priorities and implementing programs can be paramount in the region's rise. Carpathian Euroregion can play a crucial role in the adoption and implementation of operational programs for the recovery and promotion of investment, as well as for education, training and employment, which have already been approved by the project management. The governments of the Euroregion must continue their active participation and cooperation in all areas from economic to cultural and interethnic cooperation, and can be assisted directly by national minorities, which, although divided by borders, are a key element in the effectiveness of the Euroregion. Nevertheless, the Carpathian Euroregion is considerable, and therefore there is some unevenness in cooperation between the participating states. For example, cooperation between Poland and Ukraine is much stronger than cooperation between Poland and Slovakia. Of course, the first reason for such inequality in cooperation is the common historical past, as well as the presence of national minorities, which set the main trend and are the main element of the practical implementation of cooperation between the parties. Key words: cross-border cooperation, Euroregion, Carpathian Euroregion, national minorities, Ukraine, Poland. 